\title{
Up-Scaling of Fish Feed and Feeding Practice for Carps Based on Locally Available Ingredients in Mid-Hilly Regions of Uttarakhand
}

\author{
K.S. Mehta ${ }^{1}$, Priyanka Arya ${ }^{2}$, Akansha Khati ${ }^{2}$, V.K. Singh ${ }^{3}$ and H.C.S. Bisht ${ }^{4}$ \\ ${ }^{1}$ Afro Asian Development Consortium, New Delhi, India \\ ${ }^{2}$ Department of Aquaculture, College of Fisheries, G. B. P.U.A\&T, Pantnagar \\ ${ }^{3} S M S, K V K$, Lohaghat, DCFR, Bhimtal \\ ${ }^{4}$ DSB Campus, Kumaun University, Nainital, India \\ *Corresponding author
}

\section{A B S T R A C T}

The current experiment was designed for evaluation of formulated diet prepared by locally available feed ingredients rice bran, mustard oil cake, madua flour

\section{Keywords}

Feed ingredients,

Carp culture,

Proximate

composition,

Experimental diet

Article Info

Accepted:

10 November 2020

Available Online:

10 December 2020 (Ragi), soybean cake and mineral and vitamin mixture as potential basal ingredients for Chinese carp culture in mid hills of Uttarakhand. Three experimental diets (D1, D2, and D3) of different composition and the similar protein level (27-30\%) were formulated with locally available ingredients. Data on the proximate composition reflected that there was not any significant difference in nutritive value of elements in all diets. Protein level in the all diets was in the range of $27.4-30 \%$. A feed trial was conducted for standardization of the feed composition by using locally available ingredients during the month of May-June. At the end of experiment treatment fed with diet D3, showed highest net weight gained $55.78 \mathrm{gm}$ with $95 \%$ survival, SGR $3.46 \%$ and $3.1 \%$ minimum value for FCR as compared to treatments fed with D1and D2 experimental diets. The findings of the current study indicate that locally available feed ingredients from mid hill region of Uttarakhand can serve as potential basal feed ingredients for hill carp culture.

\section{Introduction}

Aquaculture is feed based industry, over $60 \%$ of operational cost coming only from feed sources with shifting from extensive to semiintensive or intensive farming, depending on farm. Replacement of fish meal with cheaper ingredients of plant origin in fish feed is necessary because of rising cost (FAO, 2013). Fish feed is main factor for fish production and it should have various properties according to the target species. The artificial feed balanced with protein, lipid, carbohydrate, fatty acids, vitamins, minerals 
and containing optimum protein/energy ration is the common practice for better yield. The fish farmers are not very well aware about the suitable feed ingredients and their proportion in the formulated feed diet. The general feed ingredients being used by fish farmer include rice bran, rice polish, oil cake and groundnut oil cakes and husk etc.

The nutritional value of food depends not only on the quantity of protein but also on the amino acids profile. Thirty per cent protein level is optimum for growth of carp fingerlings, also observed by Renukardhya and Varghese (1986); Gangadhar et al., (1997); Rangacharyulu et al., (2000); Paul and Mohanty (2002); Arya et al., (2019). Carbohydrate remain in the fish feed in the range of $15-45 \%$. Lipids are an important nutrient in the diet as a source of energy, carriers of vitamins, essentials fatty acids, sterol and phospholipids. Lipids also impart necessary flavor and thus may increase feed palatability.

Keeping in view, reduction of feed cost and ultimately production cost of fish for better return, there is an urgent need of some nonconventional feed ingredients in the diet of fish. The feed ingredients, generally provided in artificial feed are mainly the byproducts of various agricultural crops such as vegetables oil cake, rice and wheat bran \& husk etc. Traditionally supplementary feed comprising oil cake and rice bran in 1:1 ratio @ 1-2\% of fish biomass is used as fish feed. Generally supplementary feed provided to the fish by fish farmers is very low in protein (13-16\%) as majority of fish farmer provide only rice bran with husk, owing it to decrease fish yield mostly ranging between $1500-2000 \mathrm{~kg} / \mathrm{ha} /$ yr. (Singh and Sharma, 1998). Therefore, there is a need to develop nutrient balanced fish feed incorporating locally available ingredients to obtain maximum fish production and minimize the cost.

\section{Materials and Methods}

The experiment was designed for evaluation of formulated diet prepared by locally available feed ingredients rice bran, Mustard oil cake, Madua flour (Ragi), Soybean cake and mineral and vitamin mixture as potential basal ingredients for Chinese carp culture in mid hills of Uttarakhand. Three experimental diets (D1, D2, and D3) of different composition and the similar protein level (27$30 \%$ ) were formulated with locally available ingredients (Table 1). Data on the proximate composition reflected that there was not any significant difference in nutritive value of elements in all diets (Table 2 and Fig. 1). Protein level in the all diets was in the range of $27.4-30 \%$. All the three exotic species viz. silver carp, grass carp and common carp were reared in 750 liter FRP tanks for two month duration. Fingerlings of uniform size were stocked @20 nos. in each tank. Feeding was given@ $3 \%$ of the total biomass of the fish in the tank with 2 feeding frequency in a day.

Initial and final data was recorded for the growth and feed intake in each tank. Fifty percent tank water was exchanged daily to maintain the water quality parameters in optimum range. Growth rate of fish was estimated by weighing all the fish from each tank at fortnight intervals. Each diet was analyzed for the proximate composition (AOAC, 2012). On the basis of recorded data from growing fish, the most suitable composition was finalized. At the end of the experiment growth performance was evaluated by the standard formulas for specific growth rate, feed conversion ratio, condition factor, protein efficiency ratio and assimilation efficiency. Various water quality parameters such as temperature, $\mathrm{pH}$, Dissolved Oxygen (DO), free $\mathrm{CO}_{2}$ and total alkalinity were analyzed weekly throughout the trial (APHA, 2012). 


\section{Results and Discussion}

As feeding is a very important step for the successful carp farming in uplands. In the current experiment formulated diet were prepared by locally available feed ingredients rice bran, mustard oil cake, madua flour (Ragi), soybean cake and mineral and vitamin mixture as potential basal ingredients for Chinese carp culture in mid hills of Uttarakhand. Experiment was conducted in three FRP tanks (size $1 \times 1 \times 0.7 \mathrm{mt}$.) in outdoor condition at Krishi Vigyan Kendra, Lohaghat, during the month of May-June, 2008 (60 days). Three different test diets (Table 1) were formulated with locally available feed ingredients like rice bran, mustered oil cake, madua flour and soybean cake with their proximate composition (Table 2). Data on the proximate composition reflected that there was no significant difference in the level of nutritive elements of all diets. Protein level in the all diets was found in the range of 27.4$30 \%$ with almost similar level of other elements. The data on growth performance (Table 3, Fig. 2) revealed that feed D3 having $30 \%$ protein and $7.9 \%$ lipid is best among the all 3 tested diets having the feed ingredientsrice bran, mustard oil cake, madua flour (Ragi), soybean cake and mineral and vitamin mixture. In the feeding trial of 2 months with the diet D3, net weight was gained $55.78 \mathrm{gm}$ with 95\% survival and 3.1 FCR. The value of Specific Growth Rate is used to compare growth on a daily basis. Higher growth and specific growth rate (3.46) indicates that the D3 is superior over the other tested diets. Several scientists have also applied SGR as growth index in different nutritional studies Dinesh (2004) and Pandey (2005). The value of condition factors for different treatments was 1.6 (D1), 2.2(D2) and 2.1 for D3, which shows similarity with other research on ponderal index or condition factor of different fishes i.e. 0.73 to 0.95 in Tor putitora (Pathani and Das, 1980), 1.03-1.31 in Salmo trutta fario (Kumar et al., 1979) and 1.201.34) in Salvelinus namayeush (Oosten and Eshneryer, 1956). Kumar et al., (1979) concluded that the value of condition factor as about one is considered to be of its average weight. The values of $\mathrm{K}$ in present study were recorded in the range of 1.6 to 2.2 showed that the fishes of experimental unit are more robust condition. The value of the Assimilation efficiency (AE) for different 3 diets were in the range of 76.34-78.24, highest for the diet D3, and the value of the PER for different 3 diets were in the range of 24-29 with highest for the diet D3 (Table 3, Fig. 2).

Table.1 Composition of different experimental diets

\begin{tabular}{|c|l|l|l|}
\hline Diets & Ingredients & Ratio & Qty.in 1kg \\
\hline D1 & Rice bran & 49 & $490 \mathrm{gm}$ \\
\cline { 2 - 4 } & Mustard oil cake & 49 & $490 \mathrm{gm}$ \\
\hline \multirow{4}{*}{ D2 } & Mineral mixture & 2 & $20 \mathrm{gm}$ \\
\hline \multirow{5}{*}{ D3 } & Rice bran & 30 & $300 \mathrm{gm}$ \\
\cline { 2 - 4 } & Mustard oil cake & 48 & $480 \mathrm{gm}$ \\
\cline { 2 - 4 } & Madua flour & 20 & $200 \mathrm{gm}$ \\
\cline { 2 - 4 } & Mineral mixture & 2 & $20 \mathrm{gm}$ \\
\hline \multirow{5}{*}{} & Rice bran & 33 & $330 \mathrm{gm}$ \\
\cline { 2 - 4 } & Mustard oil cake & 35 & $350 \mathrm{gm}$ \\
\cline { 2 - 4 } & Madua flour & 20 & $200 \mathrm{gm}$ \\
\cline { 2 - 4 } & Soyabean cake & 10 & $100 \mathrm{gm}$ \\
\cline { 2 - 4 } & Mineral mixture & 2 & $20 \mathrm{gm}$ \\
\hline
\end{tabular}


Table.2 Proximate composition of tested carp diets

\begin{tabular}{|l|c|c|c|}
\hline CARP FEED & D1 & D2 & D3 \\
\hline Moisture & 3.97 & 4.24 & 4.12 \\
\hline Crude protein & 27.4 & 29.2 & 30.0 \\
\hline Crude lipid & 7.5 & 7.4 & 7.9 \\
\hline Crude fiber & 2.41 & 2.40 & 2.42 \\
\hline Total ash & 20.66 & 21.44 & 20.14 \\
\hline NFE & 38.06 & 35.32 & 35.42 \\
\hline
\end{tabular}

Table.3 Evaluation of different growth parameters from experimental diets

\begin{tabular}{|l|c|c|c|c|c|}
\hline $\begin{array}{l}\text { TEST } \\
\text { DIETS }\end{array}$ & $\begin{array}{c}\text { Specific } \\
\text { growth rate } \\
\text { (SGR) }\end{array}$ & $\begin{array}{c}\text { Feed conversion } \\
\text { ratio (FCR) }\end{array}$ & $\begin{array}{c}\text { Condition } \\
\text { factor (CF) }\end{array}$ & $\begin{array}{c}\text { Assimilation } \\
\text { efficiency (AE) }\end{array}$ & $\begin{array}{c}\text { Protein } \\
\text { efficiency } \\
\text { ratio (PER) }\end{array}$ \\
\hline D1 & 2.53 & 3.8 & 1.6 & 76.34 & 24 \\
\hline D2 & 3.14 & 3.2 & 2.2 & 77.82 & 27 \\
\hline D3 & 3.46 & 3.1 & 2.1 & 78.24 & 29 \\
\hline
\end{tabular}

Fig.1 Proximate composition of experimental diets

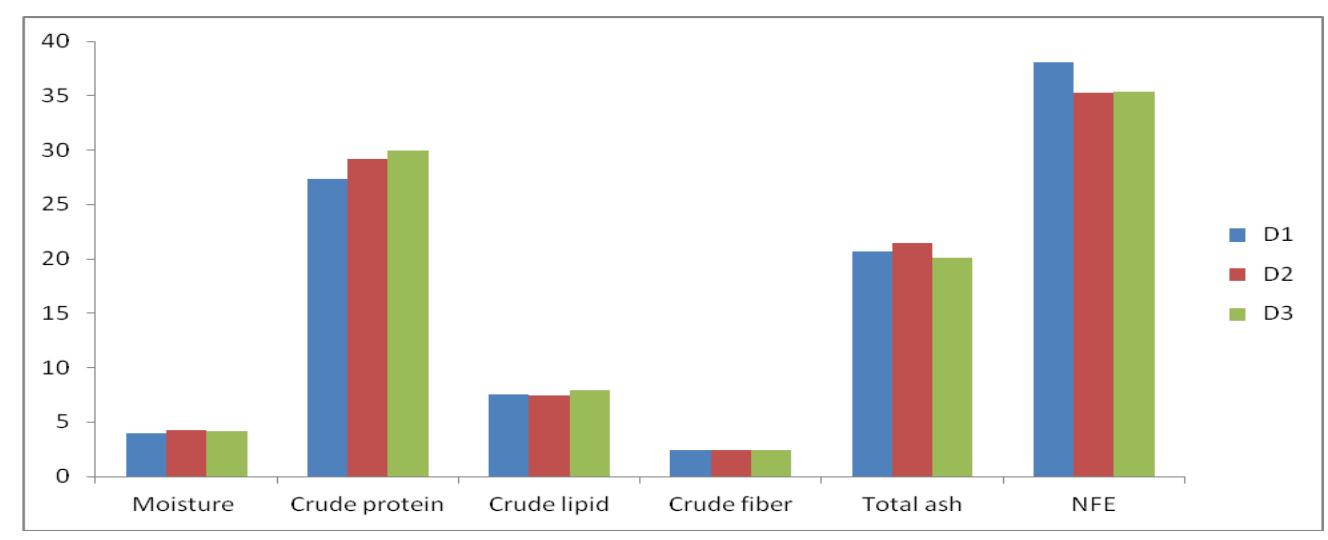

Fig.2 Evaluation of different growth parameters from experimental diets

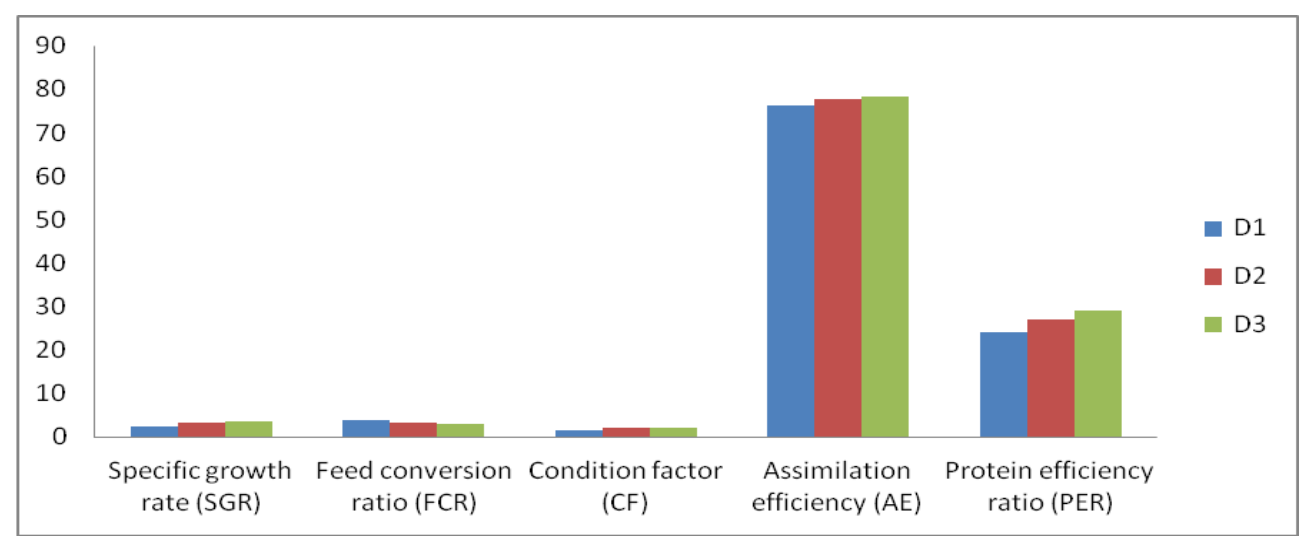


The results of the experimental study concluded that best growth performance was obtained by experimental diet D3. Therefore cost effective fish feed with $30 \%$ protein and $7.9 \%$ lipid content formulated by locally available ingredients- rice bran, Mustard oil cake, Madua flour (Ragi), Soybean cake and mineral and vitamin mixture is should be used for enhanced production in the mid hilly regions of Uttarakhand.

\section{References}

AOAC, 2012. Official methods of analysis, Association of official analytical chemist $19^{\text {th }}$ edition, Washington D.C., USA.

APHA 2012. Standard Methods for Examination of Water and Wastewater, 22th ed. American Public Health Association, New York. Pp. 541.

Arya, P., D. Chandra, A. Khati and Chauhan, R.S. 2019. Effect of probiotics supplemented diet on growth performance of Catla catla fingerlings in tarai region of Uttarakhand. Journal of Entomology and Zoology Studies. 7(6): 202-206.

Dinesh, 2004. Study on efficacy of vermin compost as organic manure and earth worm meal as protein rich supplement in feeding of Labeo rohita. M.F.Sc. thesis. 2004.

FAO, 2013. On-farm feeding and feed management in aquaculture. FAO Fisheries And Aquaculture Technical Paper, 583

Gangadhare, B., M. C. Nandeesha, J. J. Varghese and Keshavanath. P. 1997. Effect of varying protein and lipid levels on the growth of rohu, Labeo rohita. Asian Fisheries Science. 10: 139-147.
Kumar, D., U. Bhaumik and Das, P. 1979. Production cum demonstration of composite fish culture of West Bengal. In: Symposium on Inland Aquaculture, (Abs.) Feb 12-14, CIFRI, Barrackpore. Pp. 69-70.

Oosten, V. J., and Eschneryer, H. P. 1956. Biology of young lake trout (Sacvellinus namaycush) in lake Michigan. Fish Wild Survey. 42:48-55.

Pandey, N. N., 2005. Integrated Azolla PigFish farming with special reference to pond productivity and fish production. Ph.D. thesis. 2005.

Paul, B. N., and Mohanty, S. N. 2002. Recent advances in carp feeding in India. 4th Biennial Conference and Exhibition, Kolkata. 42- 48.

Pathani, S. S., and Das, S. M. 1980. A note on length weight relationship and seasonal

condition factor of mahseer Tor tor and Tor putitora (Ham.). Journal of the Inland Fisheries Society of India. 12:140143.

Rangacharyulu, P. V., B. N. Paul, S. Nandi, S. Sarkar and Mukhopadhyay, P. K. 2000. Effect of different protein and energy levels on growth, nitrogen metabolism and body composition of Rohu (Labeo rohita). Journal of Aquaculture. 8: 17-24

Renukardhya, K. M., and Varghese, T. J. 1986. Protein requirement of carps. Catla catla (Ham.) and Labeo rohita (Ham). Proc. Indian Acad. Science (Anim. Sci.)95(1):103-107.

Singh, V. K., and Sharma, A. P. 1998. Community structure of plankton in fish ponds manured with three organic manures. Himalayan Journal of Environmental Zoology.12: 91-98.

\section{How to cite this article:}

Mehta, K.S., Priyanka Arya, Akansha Khati, V.K. Singh and Bisht, H.C.S. 2020. Up-Scaling of Fish Feed and Feeding Practice for Carps Based on Locally Available Ingredients in Mid-Hilly Regions of Uttarakhand. Int.J.Curr.Microbiol.App.Sci. 9(12): 1177-1181. doi: https://doi.org/10.20546/ijcmas.2020.912.143 